\title{
Śląskość jako etniczność: refleksja o pograniczu polskości i śląskości ${ }^{1}$
}

Streszczenie: Śląsk to przestrzeń, w której splatały się dzieje Polski, Niemiec, Czechosłowacji i Czech. Tu także swe piętno odcisnęły takie wielkie ideologie jak komunizm i socjalizm. O Śląsku decyduje również polityka ekonomiczna. Śląskość to zatem przykład kultury, która kształtowała się w skomplikowanych warunkach społecznych i politycznych, decydujących o świadomości kulturowej samych Ślązaków, a także o ich tożsamości. Celem artykułu jest próba rozpoznania, jak w obrębie polskiej narracji konstruuje się polskość Śląska i jak sprzyja (lub nie sprzyja) ona emancypacji tożsamości etnicznie śląskiej. Na potrzeby tego zadania autorka dokonała analizy książki Zofii Kossak „Nieznany kraj” (pierwsze wydanie 1931), korzystając z koncepcji metanarracji Jeana-Françoisa Lyotarda. Drugim zadaniem artykułu jest refleksja wokół jednej z konsekwencji uwikłania śląskości w polskość i niemieckość, co powoduje, że Ślązacy są dla Polaków nie dość polscy i jednocześnie dla Niemców są nie dość niemieccy? Kontekstem tej refleksji są koncepcje: „kultury” jako przestrzeni wytwarzania znaczeń (Clifforda Geertza) i „świata” jako egzystencji człowieka (Václava Havla).

Słowa kluczowe: tożsamość, etniczność, tożsamość etniczna, pogranicze, śląskość, polskość

Śląsk to przestrzeń, w której splatały się dzieje Polski, Niemiec, Czechosłowacji i Czech. Takie uwikłanie w rozmaitość narodowo-państwowych narracji decyduje o wyjątkowości Ślązaków jako wspólnoty, która musiała nauczyć się trwać na przekór polityce granic i w dynamice polityki granic. Przy każdej bowiem zmianie granic Ślązacy ponosili konsekwencje wynikające z faktu ich upolitycznienia w grze o władzę nad ziemią i ludźmi. Jest to szczególnie dotkliwe wówczas, gdy wspólnota etniczna zasiedla ziemię, która jednocześnie jest ziemią graniczną każdego z następujących po sobie porządków politycznych.

1 Artykuł jest efektem pobytu dydaktycznego w Katedrze Slawistyki w Uniwersytecie Ostrawskim w Republice Czeskiej. Wyjazd został zrealizowany w ramach projektu Erasmus+ Staff Mobility for Teaching 2019/2020, w dniach 11-15 listopada 2019 r. 
Od dawna nurtuje mnie śląskość jako kulturowy fenomen; w tym artykule podejmuję zaledwie próbę (z)rozumienia śląskości/etniczności jako tego, co konstruowane jest w żywiole narracji narodowych o innych rdzeniach etnicznych. Najbardziej jednak zastanawia mnie: Czym jest powodowane to, że Ślązacy - podobnie jak Kaszubi - dla Polaków są nie dość polscy i jednocześnie dla Niemców są nie dość niemieccy, i jakie są tego konsekwencje dla śląskości? Refleksja nad etnicznością wstępnie jednak wymaga rozważenia dwóch pojęć, a mianowicie „kultury” jako przestrzeni wytwarzania znaczeń i „świata” jako egzystencji człowieka.

\section{„Kultura” jako przestrzeń wytwarzania znaczeń}

Zastanawiając się nad kulturą, można dojść do przekonania, że nie tyle kultura fizyczna/materialna decyduje o związaniu człowieka i wspólnoty z zasiedlaną ziemią, ale istotniejsza zdaje się kultura symboliczna, która jest efektem nieustannego konstruowania znaczeń wokół tego, co materialne i sytuacyjne. Za taką właśnie koncepcją kultury opowiada się m.in. Clifford Geertz, który rozumie kulturę jako sieć znaczeń (Geertz, 2005, s. 19).

Kultura jest tworem ideacyjnym, czyli znaczeniowym; jednak - jak podkreśla Geertz - znaczenia mogą być konstruowane wyłącznie publicznie. Zachowanie człowieka staje się kulturą tylko wtedy, gdy jest ono publiczne i istnieje jako część myślenia wspólnotowego. Podobnie zresztą rzecz ma się z materialnymi wytworami człowieka; nie wystarczy, że istnieją one obiektywnie, lecz muszą być one myślane przez człowieka - zawsze jednak między ludźmi, czyli społecznie. Istotą tego procesu jest społeczne ustalanie znaczeń i powodowanie, aby zarówno człowiek, jak i ludzie - w wyniku oddziaływania znaczeń - zachowywali się w konkretny sposób. Chodzi też o to, aby członkowie wspólnoty - w swym myśleniu - byli przekonani o kulturowej adekwatności własnych zachowań. Ujawnia to nie tylko społeczny i antropologiczny charakter kultury, ale przede wszystkim jej psychologiczny wymiar. Kultura to w istocie sieć znaczeń, która powinna wniknąć „w człowieka” i powinna stać się cechą jego umysłu, osobowości i struktury poznawczej (Geertz, 2005, s. 25-28). Logika kultury sprowadza się zatem do dostarczenia człowiekowi i wspólnocie praktycznej wiedzy, która wytworzy w ich kolektywnej świadomości przeświadczenia, że prawda o świecie zawarta w ich kulturze jest dokładnie tym samym, co ich świat. To kultura powoduje, że w kolektywnym myśleniu wspólnoty zatarciu ulegają granice między znaczeniem/interpretacją/narracją o świecie a światem istniejącym obiektywnie. 
Takie pojmowanie kultury sprowadza ją do rangi wiedzy pozytywnej, zadaniem bowiem kultury jest dostarczać narzędzi - w postaci wspomnianej już wiedzy praktycznej - które pozwolą (re)konstruować codzienność wspólnotową. Ta zwrotnie potrzebuje istnieć w obrębie jakiegoś porządku, a tym jest przecież kultura, która wytwarzana jest przez daną wspólnotę. Aby jednak ów porządek dostarczany/wytwarzany przez kulturę zyskał prawomocność, kultura musi potwierdzać swoją prawdziwość w praktyce - czyli w codzienności wspólnotowej - gdyż wyłącznie w ten sposób może się uprawomocnić. W grę wchodzi wobec tego imperatyw pozytywności kultury, który osiągany jest w zrównaniu jej wymiarów deskrypcji i reprezentacji. Jest to jedyny sposób, w drodze którego kultura może szukać swego potwierdzenia w rzeczywistości społecznej i psychologicznej (Foucault, 2000, ss. 127-128, 135-139). Siła kultury wynika ze szczególnej właściwości człowieka i wspólnoty: zwykle nosiciel i użytkownik kultury nie dostrzega tego, że w jego (w każdej) kulturze świat zostaje zredukowany wyłącznie do znaczenia/interpretacji/narracji czy nawet hipotezy siebie.

\section{„Świat” jako egzystencja człowieka}

Jedną z najważniejszych tez Václava Havla zdaje się ta, w której autor przekonuje, że to nie człowiek potrzebuje świata, ale jego egzystencja (Havel, 1993). Egzystencja niejako zmusza człowieka, aby uczynił on jakiś obszar świata - swoim światem. Człowiecza egzystencja jest możliwa tylko wówczas, gdy świat stanie się dla człowieka wyraźnym punktem odniesienia. Istotne w myśli Havla jest to, że człowiek nie tyle przeżywa świat, ale człowiek doświadcza i przeżywa jedynie swe odniesienie do świata, co jest możliwe wyłącznie wewnątrz świata.

Odniesienie do świata wewnątrz świata jest relacją, w obrębie której dzieje się człowiecza tożsamość i tym samym człowieczy świat to nic innego, jak atencja dla jego tożsamości. Życie człowieka nie realizuje się jednak wyłącznie w „swoim świecie”, ale przebiega ono także w świecie, który swoim nie jest. Oba te światy powodują jednakże, że tożsamość człowieka to nieuchronność jej trwania i rozpadu (Havel, 1993, ss. 13-15).

Świat w myśleniu Havla (m.in.) istnieje jako konflikt tendencji homogenizacji i tendencji twórczej, a nawet stwórczej, jak pisze autor. Homogeniczność to dążenie, aby wszystko, co wewnątrz świata, zostało ujednolicone, przemieszane i rozpuszczone. Świat homogeniczny to świat owładnięty „porządkiem śmierci”. Z kolei świat twórczy/stwórczy to dążenie, aby wszystko, 
co wewnątrz, było pielęgnowane, umacniane i chronione, gdyż ma ono indywidualny i oryginalny charakter. Twórczość/stwórczość to właściwość, która pozwala przekształcać to, co indywidualne i oryginalne, w coraz bardziej złożone struktury. Świat twórczy/stwórczy to szacunek dla nieprzezwyciężonej „woli bycia sobą"; to zgoda na to, aby człowiek „był tym, czym jest, albo czym chce być, samym sobą, aby być sobą jak najpełniej, bronić tego w sobie i pogłębiać". Twórczość/stwórczość to dochodzenie do sedna tego, co jest „wolą tożsamości" człowieka (Havel, 1993, ss. 126-127).

Człowiek może obronić swoją tożsamość tylko (Havel, 1993, ss. 19, 127): 1) poprzez konfrontację z „porządkiem śmierci”, którego celem jest zniszczenie tego, co indywidualne i oryginalne; 2) w kontekście relacji ze światem, gdyż świat to materia, która buduje życiowe alternatywy człowieka.

Świat w taki czy inny sposób zmusza człowieka do stawiania sobie pytań o sens; i choć sens rodzi się w relacji ze światem, to jednak człowiek odpowiedzi szuka w sobie, w tym, co Václav Havel nazywa nadzieją i wiarą w ogólny sens rzeczy. To dla pytań o sens człowiek potrzebuje owego - tak istotnego w myśleniu autora - punktu odniesienia, czy też punktu zaczepienia, który jest ostatecznym horyzontem poczynań człowieka, i który jest absolutnym punktem odniesienia w nieskończoności dla wszystkiego, co człowiek robi. Jest to też „pamięć bytu”, która nie daje się oszukać. To sumienie świata (etyka), które jest kryterium i tłem, i równocześnie obszarem wszystkich poczynań egzystencjalnych człowieka. To także „świadek” codziennych sposobów radzenia sobie człowieka z samym sobą; a także coś, co człowieka równocześnie chroni i przeraża swoim absolutyzmem i swoją sprawiedliwością. I być może dlatego - paradoksalnie wbrew wszystkiemu innemu - człowiek może liczyć na ów ostateczny horyzont poczynań, i dla niego właśnie chce albo musi starać się w swojej egzystencji. I najważniejsze: ten ostateczny horyzont poczynań powoduje, że człowiek od dziecka może czuć się sobą, może być istotą ludzką. Człowiek jednak nie byłby sobą, gdyby nie te rozmaite napięcia, jakie powstają pomiędzy nim i jego horyzontem (Havel, 1993, s. 18).

Ostateczny horyzont ludzkich poczynań to konstrukt, który złożony jest z podstawowych warstw: horyzontu otoczenia, konkretnego/prawdziwego horyzontu egzystencji i horyzontu absolutnego. Horyzont otoczenia to najbliższy człowiekowi świat fizyczny, w którym ten musi się zadomowić. Nie musi to być jednak konkretny/prawdziwy horyzont człowieczej egzystencji (Havel, 1993, s. 29). Ten może się skrywać za horyzontem otoczenia; nigdy jednak nie jest on ostateczny i absolutny, gdyż nieustannie się zmienia. Konkretny i prawdziwy horyzont człowieczej egzystencji to struktura tego, co 
Havel nazywa „egzystencjalnym domem”. Rozwija się on powoli, a w tym rozwoju zmieniają się znaczenia, jakie człowiek nadaje różnym ludziom, relacjom, środowisku, zobowiązaniom, wartościom, sympatiom i obawom. Elementem tego horyzontu jest moralny i duchowy aspekt porozumienia człowieka z ludźmi, którzy (w przeszłości i/lub aktualnie) tworzą jego egzystencjalny horyzont (Havel, 1993, s. 29). Stąd też w myśli Havla pojawia się wspomniana metafora „egzystencjalnego domu” jako fizyczności i duchowości konkretnego horyzontu człowieczej egzystencji. Duchowość jednak jest tym, co wydaje się istotniejsze niż fizyczność. Utrata „domu w jego fizyczności" powoduje, że uobecnia się on w abstrakcyjnej formie, jako przejaw egzystencjalnej samoobrony. Utracić „dom” w jego aspekcie „fizycznym” oznacza utracić wolność, a wraz z nią ludzi i wartości. W utracie „domu fizycznego” objawia się egzystencjalna logika "domu” jako tego, co zmusza człowieka do wyboru (Havel, 1993, s. 32). Utrata „fizycznego domu” jest czymś natarczywym dla człowieka; czymś, co jednocześnie może skupiać świadomość na aspekcie duchowym, który skrywa się za fizycznością i w tej pozycji często jest doświadczany nieświadomie. „Duchowość domu” to całość, to zespół wartości, które zdają się powodować, że „świat domu” staje się dla człowieka nadzieją, gdyż to tu tkwi sens wszystkich jego właściwych poczynań. Dopiero poprzez akt utraty „domu duchowego” objawia się jego istotność: utracić "dom” to jak - zauważa Havel - utracić raj (Havel, 1993, s. 31). Utrata ta bowiem uzmysławia człowiekowi to, za czym i jak tęskni, o czym i jak myśli oraz wspomina, co i jak sobie wyobraża oraz czego pragnie (Havel, 1993, s. 30).

Za konkretnym egzystencjalnym horyzontem ukrywa się trzeci (Havel, 1993, s. 29): „to jest najbardziej nierzeczywisty, najbardziej abstrakcyjny, najgłębiej ukryty i najtrudniej uchwytny, równocześnie jednak, co wydaje się paradoksalne, jakby najbardziej pewny (trwa nawet wtedy, gdy wszystko, co konkretne, zawali się) i najbardziej stały, ostateczny i absolutny (jako absolutny widnokrąg wszystkich względnych w życiu spraw) - i to jest ten horyzont (...), który - jako metafizyczny punkt w nieskończoności życia i jako punkt nadający życiu sens - niektórzy nazywają Bogiem" (Havel, 1993, s. 30). Horyzont absolutny nie jest doświadczeniem religijnym, jak by się mogło zdawać z powyższej wypowiedzi. Dla Havla jest to doświadczenie metafizyczne i jest ono skrycie obecne we wszystkich egzystencjalnych doświadczeniach człowieka. Stąd szukanie sensu życia jest poszukiwaniem absolutnego horyzontu. Więcej: bez absolutnego horyzontu, bez tych metafizycznych doświadczeń, jakie rodzą się w wyniku doświadczania przez człowieka tego odniesienia, jego egzystencja nie byłaby egzystencją ludzką. Człowiek nie mógłby w ogóle 
istnieć jako ten, którym on jest, czyli jako twórca/stwórca nowego (duchowego) świata (Havel, 1993, ss. 86-87). Jest to horyzont, który uszlachetnia człowieka, ponieważ pozwala mu „wznosić się” do „sensu ogólnego” i materialnej strony egzystencji (Havel, 1993, ss. 46-47).

Dlatego też, jak się wydaje, w myśli Havla ostateczny horyzont człowieczej egzystencji to odpowiedzialność, która dzieje się pomiędzy ludźmi. Autor pisze o odpowiedzialności, która sprawia, że człowiek w relacji z człowiekiem pośród ludzi konstruuje swoją tożsamość. Dom i środowisko rodzinne nadają sens temu, co człowiek robi. To zaplecze tworzące „dom egzystencjalny” i otwierające wrota do horyzontu absolutnego, gdyż tu tworzą się nie tylko znaczenia kulturowe, ale tu tworzą się metafizyczne doświadczenia będące efektem codziennej egzystencji w kulturze. „Dom egzystencjalny” może być przed człowiekiem ukryty i przez to może być mu daleki. Kiedy jednak dom i środowisko rodzinne stają się niedostępne, to człowiek musi świadomie odnosić się do nich, jako do konkretnego horyzontu swej egzystencji. Więcej, musi to być żywy i ciągły temat jego egzystencji, tylko bowiem w ten sposób człowieka mogą zacząć nurtować rozmaite sprawy (Havel, 1993, s. 28), szczególnie te dotyczące tego, co kształtuje jego tożsamość. To stąd dla Havla ludzka egzystencja jest powtórnym (s)tworzeniem świata (Havel, 1993, s. 67). Wobec takiej konkluzji człowiek Havla może być wyłącznie „bytem pytającym”. Człowiek to byt - pisze autor - „który pyta sam o siebie, a jeszcze ściślej jest on tym, którego ustami byt pyta sam o siebie" (Havel, 1993, s. 76). I dlatego człowiek Havla może sam wybierać swoją społeczną wolność i sam może decydować o tym, jak się ona realizuje (Havel, 1993, s. 26).

\section{Śląskość jako polskość - śląskość jako niemieckość}

Polskość i niemieckość w odniesieniu do śląskości zachowują się jak Lyotardowskie metanarracje; ich celem jest nasączanie śląskości określonego rodzaju wiedzą o polskości i niemieckości, tylko po to, by przetwarzać śląskość w polskość lub w niemieckość. Te z kolei w praktyce muszą realizować przywołany wcześniej Foucaultowski imperatyw pozytywności kultury. Tylko bowiem w taki kulturowy sposób - jako formuła wiedzy - mogą one osiągnąć swój praktyczny cel, którym jest wytwarzanie społeczeństwa jako całości. Taka wiedza może jednak istnieć wyłącznie jako zespół warunków wytwarzających, podtrzymujących i pozwalających praktykować określonego rodzaju homogeniczną jedność (tu: jako polskość lub jako niemieckość). Ale rozpoznanie tego mechanizmu wymaga krytycznej świadomości tego, 
że każde społeczeństwo (i to homogeniczne, i to heterogeniczne) do swego funkcjonowania potrzebuje narracji, gdyż tylko ona może dostarczać wiedzy o potrzebnej mocy konsolidującej, która jednocześnie stanie się częścią człowieczej egzystencji (por. Lyotard, 1997, ss. 34, 47-55).

\section{Bogactwo (w) ziemi}

W odniesieniu do Śląska (i nie tylko) antagonizm polsko-niemiecki w swej radykalnej formie skonceptualizował się w okresie międzywojennym, kiedy toczyła się otwarta polityczna walka o Śląsk, chociaż - co trzeba podkreślić - konflikt pomiędzy tym, co polskie a tym, co niemieckie dochodził do głosu wcześniej i stopniowo oraz znacząco radykalizował się w XIX w., czyli w okresie zaborów. Z drugiej jednak strony wystarczy wrócić pamięcią do kursu historii z zakresu szkoły średniej, aby uzmysłowić sobie fakt, że nie tylko zabory przyczyniły się do radykalizacji antagonizmu polsko-niemieckiego w walce o Śląsk. Tym, co zaostrzało spór, były także naturalne zasoby Śląska, szczególnie węgiel, nazywany „czarnym złotem”. Dobrą tego egzemplifikacją są słowa Ferdynanda Goebla, który pisał w 1934 r.: „(...) z Niemcami spieraliśmy się o fabryki i kopalnie i wszelki związany z nimi stan posiadania, nie dopuszczając niejako myśli o istnieniu i potrzebie rewindykacji jakichś wartości duchowych, związanych z przyłączonymi do Polski dzielnicami. (...) Przypomnę jednakże: w chwili, gdy obliczaliśmy dokładnie każdy obiekt przemysłowy na Śląsku, każdą maszynę, każdy niejako pokład, pokładzik i kawałek węgla, każde zabudowanie, każdą grudę rudy i każdy mórg ornej ziemi - przeoczyliśmy całkowicie dobro duchowe i zlekceważyliśmy je zupełnie, jako czynnik rokowań" (Goetel, 1934c, s. 5).

Tak więc w okresie międzywojennym Śląsk miał dać swe bogactwo odradzającej się Drugiej Rzeczpospolitej (Kossak, 1961, s. 288), dokładnie na takiej samej zasadzie, jak wcześniej przynosił bogactwo Niemcom. Wiązało się ono z węglem, szczególnie wtedy, kiedy węgiel zaczął płynąć do Ameryki „cudacznymi okrętami z kominem” (Kossak, 1961, ss. 203, 190). Dlatego być może pojawiło się owo niemieckie niezadowolenie z politycznej mapy Śląska, która obowiązywała w międzywojniu, co znajduje odzwierciedlenie w słowach jednego z bohaterów (młodego Ślązaka-Niemca) powieści Horsta Bienka „Wrześniowe światło”: „Odbierzemy Polakom to, co nam zabrali, i jeszcze spory kawałek na dokładkę, naturalnie [wyróżnienie H.B.]” (Bienek, 1994, s. 24); czy też powojenne hasło z hal targowych Hanoweru, w których zbierali się ocalali Ślązacy: „Śląsk pozostanie nasz” - o czym pisał Horst Bie- 
nek w książce „Podróż w krainę dzieciństwa. Spotkanie ze Śląskiem” (Bienek, 1993, s. 285).

Węgiel i sposoby jego wydobycia spod ziemi konstruują późniejsze ekonomicznie waloryzowane dzieje Śląska. Przed epoką węgla wydobywanego na przemysłową skalę Śląsk był postrzegany poprzez bogactwo płynące ze swych ziem i lasów. Był więc traktowany jako spichlerz, a nie jako skarbiec gdyż tak zaczęto myśleć o Śląsku, od czasów, gdy nauczono się wydobywać węgiel przemysłowo. Zofia Kossak w „Nieznanym kraju”, beletryzowanym przewodniku po polskiej historii Śląska, przekonuje nawet, że ziemia śląska wcześniej nie była tak atrakcyjna dla polityki polskiej jak ziemie na Wschodzie. Stąd - jak można wnioskować ze słów autorki - zarzut stawiany Polsce, iż od czasów panowania Jagiellonów jej polityka skupiała się na Wschodzie, na ziemiach Ukrainy i Dzikich Polach, i nie troszczyła się o śląską ziemię. Być może to ówczesna niska wartość ekonomiczna spowodowała, że Rzeczpospolita zatrzasnęła przed Śląskiem „swe drzwi” i „nikt tych drzwi przez wieki nie otwierał" - jak metaforycznie zauważa autorka - i być może z tego powodu w Polsce o Śląsku zapomniano (Kossak, 1961, ss. 107-108, 289). To zapomnienie wydaje się jedną z głównych przyczyn pozostawienia Śląska na pastwę niemieckości, jak zdają się przekonywać kolejne stronice książki „Nieznany kraj”.

\section{Przeszłość i (jej) narracja historyczna}

Zarzut opuszczenia wydaje się ciężkim grzechem Polski wobec Śląska. Kossak wprost pisze, że Śląsk był „niby dziecko ciepnięte za płot, pozbawione pokarmu matczynego”. Spotykali się także Ślązacy z zarzutem ze strony Polaków, że nie są oni Polakami, co - jak pisze autorka - wykorzystywali Niemcy, wypominając Ślązakom: „Garniecie się do Polaków, a oni na was tyłek wypinają" (Kossak, 1961, ss. 223, 253, 256). Ale też przy całym tym opuszczeniu i niemieckich prześladowaniach Śląsk pozostał polski, a jego mieszkańcy Polakami. W tych - pomimo wszystko - polskich dziejach Śląska Ślązacy to „niezłomni stróże dziejowych kopców piastowskich”, którzy przetrwali wieki, nie tracąc swej odrębności (Kossak, 1961, s. 220-222). Naturą bowiem śląskości jest wytrwały opór, który jest jak „bezmierny” i „wielowieczny” śląski ciężar (Kossak, 1961, s. 207); ale tylko dzięki temu oporowi - jak sugeruje Kossak - Śląsk „pozostaje uparcie polski” (Kossak, 1961, s. 198).

W przypadku Śląska sprawa nie jest jednak tak oczywista jak w przypadku ziem centralnych, których polskości nie trzeba uzasadniać. Polskość Śląska 
musi być udowodniona, co stało się priorytetem polityki Drugiej Rzeczpospolitej, lecz dopiero na przełomie lat 20. i 30. XX w. Chodziło przecież o wytworzenie „kultury śląskiej pod panowaniem polskim” (Goetel, 1934c, s. 5), ponieważ Polska „musi być jedna wszędzie”. Kiedy więc zakończyła się walka zbrojna o Śląsk, rozpoczęła się walka o „utrwalanie i ugruntowanie” zwycięstwa poprzez kulturę polską (Goetel, 1934b, s. 5). Polacy jednak nie znali polskiej historii Śląska, gdyż tej zwyczajnie nie było w polskiej świadomości narodowej, z tej przyczyny, że Polacy o Śląsku zapomnieli. Jednocześnie Ślązacy - chyba właśnie na skutek owego polskiego zapomnienia - niewiele wiedzieli o Polsce (Kossak, 1961, ss. 167, 184, 223, 256).

Logika polskiej polityki kulturowej - w ramach prezentowanej narracji - koncentrowała się na rozbudzeniu w społeczeństwie Śląska świadomości polskości, przełamaniu wiekowej bierności Śląska i duchowym połączeniu Śląska z Polską. To zaś znaczyło jedno: wypowiedzieć wojnę „potędze niemieckiej”. Taka wojna potrzebowała jednakże, aby Ślązacy „zniknęli” jako Niemcy i narodzili się jako „zażarci” Polacy (Kossak, 1961, ss. 172, 188). Chodzi bowiem o to, by narodowość czuć (Kossak, 1961, ss. 276, 271, 283), a nie tylko pojmować ją na poziomie świadomości. Chodzi o więcej niż świadomość, chodzi o to, aby poprzez to miłowanie oddać Polsce życie. Bo jeśli zdarzyłoby się, że Polska miałaby zniknać jako naród, to - jak pisze Zofia Kossak, charakteryzując Ślązaków z Górnego Śląska - „Górnoślązak byłby ostatnim żywym Polakiem na świecie, ostatnim, co by swej mowy i odrębności narodowej zapomniał" (Kossak, 1961, s. 290).

Polskość Śląska może być osiągnięta nie tylko poprzez wykazanie wspólnej przeszłości, ale jeszcze poprzez wytworzenie wspólnej teraźniejszości i wspólne dążenia do wspólnej przyszłości. Wyobrażenie teraźniejszości i przyszłości jest możliwe tylko w sytuacji posiadania przeszłości. Jeśli zatem teraźniejszość i przyszłość Śląska mają być polskie, to wymagają one - jak zauważa Kossak - „wyłączenia polskiej przeszłości Śląska” (Kossak, 1961, s. 263-278).

Polska historia Śląska rozpoczyna się tuż po chrzcie Polski, w czasach panowania Piastów. Kossak nie rezygnuje jednak z „wyprowadzenia” polskiej historii Śląska przed chrześcijaństwo. Stąd mowa o starożytności polskiej kultury Śląska w takich sformułowaniach jak „świetność starożytna Piastów śląskich” (Kossak, 1961, s. 73), „starożytna gościnność dworu Elżbiety Lukrecji księżnej śląskiej” (Kossak, 1961, s. 90) czy „starożytne tradycje, pełne wielkości" (Kossak, 1961, s. 170). 


\section{Mowa i język}

Autonomia śląszczyzny w polskiej narracji Śląska jest trudna do rozpoznania. Dowodzi tego lektura analizowanej w tym artykule książki „Nieznany kraj”, w której konstruowanie statusu mowy śląskiej konsekwentnie zmierza do tego, by w końcowym etapie orzec o jej gwarowości. Przy czym narracja wokół mowy śląskiej - podkreślam, mowy, a nie języka - jest elementem konstruowania narracji, której celem jest udowodnienie, że śląskość to polskość.

Status śląszczyzny zmienia się zależnie od etapu przedstawianych dziejów. Im wcześniejsze polskie dzieje Śląska, tym bardziej oczywista autonomia mowy śląskiej. Kossak odnosi się do zbioru praw Zygmunta Jagiellończyka, wedle których na Śląsku mowa śląska dopuszczalna jest w sądach obok mowy polskiej, morawskiej i czeskiej. We fragmentach, w których autorka odwołuje się do spraw narodowo-językowych - początkowo używa pojęć „mowa polska” bądź "gadać po polsku" (Kossak, 1961, ss. 50, 62, 80, 81, 116, 117, 148, 176, 177) i - co istotne - pojęcia te odnoszą się do umiejętności nie tylko mówienia, ale i kreowania określonej kulturowo codzienności. Kiedy jednak w konstruowanych dziejach Śląska wzrasta świadomość polskiej odrębności narodowej Ślązaków, pojawia się także pojęcie „język polski” (Kossak, 1961, ss. 147, 177, $178,180,201,225,268)$. W konsekwencji, od momentu, w którym autorka wprowadza pojęcie ,język polski”, rozpoczyna tworzyć dla niego odrębną przestrzeń w konstruowanej narracji. „Mówienie po polsku” wiąże się z umiejętnością i praktyką typową dla polskiej codzienności, natomiast pojęcie „język polski” odnosi się do takich spraw jak: pisanie (Kossak, 1961, ss. 147, 177, 178), literatura (Kossak, 1961, ss. 177, 178, 180), kultura (Kossak, 1961, s. 68), edukacja (Kossak, 1961, s. 225) i prawo do własnego języka (Kossak, 1961, ss. 180, 201). Idzie więc o to, co Kossak nazywa pracą umysłową, do wykonania której niezbędny jest język (Kossak, 1961, s. 177). Nie istnieje w tak konstruowanej narracji pojęcie „język śląski” czy „mówienie po śląsku”. Wytwarzane jest jednak przekonanie, że co śląskie, to polskie (Kossak, 1961, ss. 184, 263, 278), co w efekcie przygotowuje grunt do wyartykułowania najważniejszej tezy konstruowanej polskości Śląska, czyli do użycia pojęcia "gwara śląska”.

Nadmienić również trzeba, że w konstruowanej narracji znalazło się także odniesienie do mowy cieszyńskiej, która w dzisiejszym strukturalnym językoznawstwie nazywana jest gwarą zachodniocieszyńską. W tym wątku narracji pojawia się co prawda pojęcie "mówić po śląsku” (Kossak, 1961, ss. 180, 201), lecz w znaczeniu „swojackiej mowy” czy też „waszej mowy”, która jest 
bliska językowi polskiemu. Trudno jednak orzec, czy jest to mowa polska, czy też nie. Problem tym trudniej rozstrzygnąć, że dzieci z ziemi cieszyńskiej uczyły się „mozolenie liter z czeskiego ślabikarza, by składać z nich wyrazy niemieckie, których znaczenia nie znały" (Kossak, 1961, s. 146-148). Zbadanie tego wątku wymaga jednakże odrębnych badań w obszarze śląszczyzny, gdyż mowa cieszyńska stanowiła przedmiot sporu pomiędzy językoznawcami czeskimi (m.in. Adolf Kellner) i polskimi (m.in. Karol Dejna) o Zaolzie. Pierwsze wydanie „Nieznanego kraju” wychodzi w 1931 r., natomiast badania gwary zachodniocieszyńskiej Adolf Kellner, językoznawca czeski, rozpoczyna w 1937 r. Niemniej jednak spór o Zaolzie między Drugą Rzeczpospolitą a Czechosłowacją rozpoczął się wcześniej, a jego rozstrzygnięcie było znaczące dla obu sąsiadujących państw. Dlatego też usilnie poszukiwano kulturowych argumentów albo za czeskością tego regionu, albo też za polskością. Druga wojna światowa spowolniła debatę w tej sprawie; na nowo rozgorzała ona po zakończeniu wojny (Bogoczová, 2018).

Wracając do głównego wątku tekstu; aksjomatycznym jądrem konstruowanej przez Kossak polskości jest twierdzenie: „Polska jest ważniejsza niż Śląsk... Najpierw musimy myśleć o niej, a potem o Śląsku”. Takiej deklaracji wymaga dobro Polski (Kossak, 1961, s. 280-281), gdyż „Polska jest całością, a Śląsk tylko jej częścią". Dla tak konstruowanej narracji podbicie rangi Polski automatycznie obniża prestiż Śląska, co wydaje się koniecznie, gdyż zrekonstruować się musi hegemonia Polski wobec jej regionów. Jest to konieczna strategia budowania prestiżu, nawet za cenę tego, że „[t]akiego (...) przeniesienia Polski nad Śląsk nigdy (...) Ślązacy nie darują" (Kossak, 1961, s. 282).

Jest to także moment ustanowienia hegemonii języka polskiego nad językiem śląskim, który od tego momentu zyskuje status gwary. Od tej chwili język śląski jest „piękną gwarą śląską, dostojną w swej zachowanej archaiczności form" (Kossak, 1961, s. 232). W kontekście badanego tekstu trzeba jednak postawić pytanie o to, czym w istocie jest gwara? Otóż jest to co prawda mówienie po polsku od czasów prasłowiańskich, ale nie jest to „inteligentne” mówienie po polsku, gdyż ma miejsce w zagrodach i siołach (Kossak, 1961, s. 338).

\section{Katolicyzm, kłopotliwość protestantyzmu i śląskie wierzenia}

Dowodem na polskość Śląska jest katolicyzm. Do czasów reformacji Śląsk był chrześcijański i w świadomości wielu istniało przeświadczenie, że Bóg 
sprzyja tym, którzy są u siebie i walczą o wolność swego domu (Kossak, 1961, ss. 24, 26). Od czasów reformacji Śląsk - za wyjątkiem Śląska Cieszyńskiego - jest katolicki. Ludność Śląska Cieszyńskiego została podzielona „różnicą wyznaniową”, co jest „bolesnym problemem i całkowicie zbędnym”. Wiara chrześcijańska powinna być jedna, tak jak jeden jest Bóg, chociaż Ten nie zwraca uwagi na formę. Chodzi jednak o to, by jedna była wiara, jeden Kościół i jedna wspólna modlitwa w języku ojczystym. Logika trwania wiekowej, śląskiej odrębności jest efektem związku wychowania narodowego i wiary w Boga. Swoją odrębność Śląsk zawdzięcza pacierzowi odmawianemu „uparcie po polsku”; bez modlitwy w języku polskim „zawiędłoby dawno (...) poczucie polskości" (Kossak, 1961, s. 229).

Śląsk Cieszyński był gościnny w swych dziejach i przyjmował protestantów wypędzonych z Polski, by mogli oni tu żyć zgodnie z katolikami (Kossak, 1961, ss. 91-92). Jakkolwiek swoistą cechą protestantów (w ogóle) jest opowiadanie się na niemczyzną, to jednak protestanci ze Śląska to „najdawniejsi Polacy”, jak przekonuje jeden z bohaterów książki. Swoistym darem protestantów było zaszczepienie w Ślązakach ciekawości różnych spraw i umiłowanie książek. Czytelnictwo i miłość do książek to „błogosławiona skłonność umysłów" (Kossak, 1961, ss. 236-237).

Trudno jednak w konstruowanej narracji dostrzec w miarę wyraźny wątek słowiański. Słowiańskość sprowadzona została do zasygnalizowania kulturowej odmienności Śląska w antagonistycznej relacji do germańskiego kręgu kulturowego. Tak więc Ślązacy to lud słowiański, a sama słowiańszczyzna ulega zagładzie przez Niemców (Kossak, 1961, s. 36), przez ich panowanie na Śląsku. Słowiańskość pozwoliła także zasygnalizować kulturową łączność mowy polskiej z innymi mowami słowiańskimi (Kossak, 1961, ss. 80, 100), gdyż Polacy od czasów prasłowiańskich mówią po polsku (Kossak, 1961, s. 338), nawet sądy ziemskie stały tu sądami słowiańskimi (Kossak, 1961, s. 80).

Słowiańskość to kolejny argument, z którego korzysta Zofia Kossak, aby podnieść rangę kultury polskiej i języka polskiego poprzez wyprowadzenie ich dziejów przed epokę chrześcijańską. Kłopotliwe zdają się jednak wszelkiego rodzaju zachowane na Śląsku wierzenia niechrześcijańskie. Trudno nawet rozpoznać w nich wyraźnie artykułowane cechy wierzeń słowiańskich.

Wierzenia śląskie są podzielone wedle światów, w których Ślązak egzystuje. Są więc wierzenia związane z żywiołem ciemności, a więc z kopalnianym życiem. Tu górnicy obcują ze Skarbnikiem, skrzatami ziemnymi, a także z martwicami. „Ludzie wierzchowi” otaczają górników szacunkiem 
i podziwem, ale też pewnym dystansem, który jest wynikiem obaw „przed nieczystymi stworami, co snadno mogły się w fałdach ich odzieży przytaić, by na świat wychynąć" (Kossak, 1961, s. 46). W życiu naziemnym, wśród „ludzi wierzchowych” żyją inne śląskie strachy, jak powiarki czy bandurki, dlatego też świat śląski - dorośli i dzieci - wierzy w strachy. Problemem jest jednak polska szkoła, która kwestionuje te śląskie wierzenia, twierdząc, że żadnych strachów nie ma. To w konsekwencji powoduje, że polscy nauczyciele nie cieszą się estymą Ślązaków (Kossak, 1961, ss. 227-228). Elementy śląskich wierzeń stoją wyraźnie w sprzeczności z ideami chrześcijaństwa, które okazały się w efekcie silniejsze i żywotniejsze, dlatego - być może - że są młodsze niż idee słowiańskie stojące za śląskimi bóstwami. Kossak pisząc, że Skarbnika w kopalni z czasem zastąpiła św. Barbara, równocześnie zauważa, że kiedy jedne wierzenia umierają, to nowe się rodzą, „bo człowiek zbyt samotny czułby się bez nich w obliczu żywiołu" (Kossak, 1961, ss. 293-294).

\section{Niemiec jako jądro narracji polskiej}

Sednem narracji polskiej jest Niemiec. Bez pewnej liczby Niemców Polacy „nie czuliby w sobie, że trzeba być narodem” (Kossak, 1961, s. 226), jak przeczytać można na stronach „Nieznanego kraju”. Można więc mniemać, że polskie dzieje Śląska muszą być w jakiś sposób powiązane z niemieckimi dziejami tej ziemi. Polskość Śląska - jak pisałam - sięga czasów słowiańskich, a nawet prasłowiańskich i starożytnych. Niemieckość jednak to też sprawa długiego trwania, gdyż Śląsk był/jest wieczyście niemiecki (Kossak, 1961, s. 286). Niemcy uznają, że Śląsk „[n]igdy, przenigdy polski nie był! Do Polski nie należał, nie miał z nią nic wspólnego! To perła korony Habsburgów!" (Kossak, 1961, s. 117). Być może takie przekonanie powoduje, że Niemcy żyjący na polskim przecież Śląsku nie chcą uczyć się języka polskiego (Kossak, 1961, s. 55). Uznają oni język polski za dialekt (Kossak, 1961, ss. 117, 170, 197), narzecze analfabetów (Kossak, 1961, ss. 170, 268) czy też chłopskie narzecze (Kossak, 1961, s. 171). Tylko język niemiecki osiągnął status, który pozwala mu być językiem światowym, czyli takim językiem, w którym narody mogłyby się komunikować między sobą, co może zaprowadzić na świecie pokój (Kossak, 1961, ss. 198, 268). Niemiecki jest więc językiem lepszym (Kossak, 1961, ss. 119). To „kulturalny, oświecony język” (Kossak, 1961, ss. 268), dlatego też nauczycielem w szkole na niemieckim Śląsku może być ten, kto uznaje język niemiecki za swój język macierzysty (Kossak, 1961, s. 197-198). 
Jest to język ludzi wykształconych, którzy dzięki edukacji w języku niemieckim lokowali się wyżej w drabinie społecznej Śląska (Kossak, 1961, s. 329).

Kształcenie w niemieckiej szkole zniemcza dziecko i powoduje, że staje się ono niemieckie. Toteż szkoła ma swój udział w zniemczaniu inteligencji, co jest rzeczą jakby naturalną w sytuacji, gdy ma ona dostęp tylko do jednej, bo niemieckiej ścieżki edukacyjnej (Kossak, 1961, s. 329). Asymilacja w język i kulturę niemiecką to wobec tego naturalne następstwo celowo prowadzonej niemieckiej polityki kulturowej. Są też tacy zniemczeni Ślązacy, który przyjęli niemieckość ze względu na własny interes (Kossak, 1961, s. 122, 269).

Niemcy nie szanują polskiej mowy, uważają, że w niej nie jest możliwa praca intelektualna (Kossak, 1961, s. 177). Więcej, Niemcy gardzą Ślązakami (Kossak, 1961, s. 85), uważają Ślązaków za hołotę (Kossak, 1961, s. 117) i bydło (Kossak, 1961, s. 122), a nawet porównują „ludność śląską do pędraka ziemniaczanego" (Kossak, 1961, s. 174).

Jak się wydaje, konsekwencją takiej postawy jest to, że Niemcy są znienawidzeni tak przez lud śląski (Kossak, 1961, ss. 49, 85, 86), jak i przez jego polskie elity (Kossak, 1961, s. 51). Niemcy są obcy na Śląsku (Kossak, 1961, ss. 50, 54, 85), tak jak obca jest dla tej ziemi ich kultura i język (Kossak, 1961, ss. 50, 54, 254). Niemcy nie tylko niszczą polskość Śląska, ale - jakby tego było mało - rabują śląską ziemię z jej dóbr (Kossak, 1961, ss. 55, 203-204).

Więcej, Niemcy w swej negatywności do Polski posuwają się do tego, że przekonują tych Ślązaków, którzy pragną, aby Polska wróciła na Śląsk, że Niemcy są bardziej gospodarni (Kossak, 1961, s. 144), a Polacy z Polski będą się znęcać nad niemieckimi Ślązakami (Kossak, 1961, s. 271). Dlatego też jak się wydaje - trzeba podjąć walkę z Niemcami (Kossak, 1961, s. 245).

\section{Dobry Polak - zły Niemiec}

Nic zatem dziwnego, że konsekwencją powyższych przeświadczeń jest to, że w polskiej narracji ukształtował się uogólniony, negatywny obraz kultury niemieckiej. Artykułowana w „Nieznanym kraju” niemieckość jest nie tylko obiektywizacją ukształtowanej w Drugiej Rzeczpospolitej narracji, jest to także obiektywizacja istniejącego od epoki prasłowiańskiej i starożytnej - jak zdaje się przekonywać Kossak - aksjomatycznego zła, które Polacy przypisują Niemcom. Niezależnie od tego, jak bliskie albo jak dalekie od niemieckich intencji były konstruowane w tej narracji przekonania, to zło przypisane niemieckości stanowi trzon antagonizmu, jako jedynej dopuszczalnej relacji między tym, co polskie a tym, co niemieckie. 
Antagonistyczna relacja polskości i niemieckości znajduje swoją - chyba najlepszą - reprezentację w książce Kossak pt. „Kłopoty Kacperka, góreckiego skrzata" (2014). I choć jest to utwór dedykowany dzieciom, to stanowi on przestrzeń jednego z najlepiej wyłuszczonych antagonizmów narodowych, które łączy niemal atawistyczna negatywność. Tego bowiem zdaje się wyraźnie potrzebować zradykalizowana w dwudziestoleciu międzywojennym polska świadomość narodowa. Zaczerpnięta z „Nieznanego kraju” wypowiedź, że bez pewnej liczby Niemców Polacy „nie czuliby w sobie, że trzeba być narodem" (Kossak, 1961, s. 226), dobrze ilustruje powyższą tezę.

Niemieckość - w tak konstruowanej polskiej narracji - obiektywizuje się wprost w złym Niemcu, z kolei polskość obiektywizuje się wprost w dobrym Polaku. Polskość wznosi murowany dom na Śląsku, jest katolicka i pobłogosławiona przez księdza. To właśnie ze związku tego trudu budowania, katolicyzmu i dobroci powstały warunki do tego, aby zrodzić się mogła śląskość. Przy czym śląskość w książce „Kłopoty Kacperka...” jest metaforycznie przedstawiona jako skrzat Kacperek, który nie jest polskim skrzatem, ale podciepkiem, czyli śląskim skrzatem domowym. Takie skrzaty zamieszkują zwykle stare polskie domy (Kossak 2014, ss. 5-11). Na tym tle niemieckość jawi się jeszcze bardziej zła, niż w rzeczywistości mogła(by) być. Niemcy „byli obcy, niemili i Kacperkowi trudno było zżyć się z nimi, nie miał jednak prawa opuścić domu, którego był duszą i stróżem" (Kossak, 2014, s. 7). Niemcy murowany dom zmienili w „spichlerz pełen pajęczyn i szczurów - a na dole mieszkał gruby, hałaśliwy Niemiec, który łajał swoje dzieci, pił ciągle piwo i nie lubił psów, ani żadnych zwierząt" (Kossak, 2014, s. 5).

Polskość i niemieckość jest tym, co przychodzi, pozostaje przez jakiś czas, wprowadza swój porządek, a następnie - w taki czy inny sposób - odchodzi. Jedyną trwałością ziemi śląskiej jest związana z nią śląskość. W polskiej narracji Niemcy są obcy i niemili, a Ślązakom trudno jest z nimi współżyć. Ale - dokładnie tak samo jak śląski skrzat Kacperek - nie mają oni „(...) prawa opuścić domu, którego (...) [są - uzupeł. A.K.] duszą i stróżem” (Kossak, 2014, s. 7). Innymi słowy, o ile polskość i niemieckość to dynamika przychodzenia i odchodzenia i w swej dynamice są one antagonistycznie związane ze sobą, o tyle śląskość to trwanie, bierność i czekanie na kolej wydarzeń. Jedynym zadaniem śląskości w tym trwaniu jest wytrwanie; tym zaś, co powinno pomóc w owym wytrwaniu, jest rozmyślanie o przeszłym życiu i pamiętanie dziejów nawet wtedy, kiedy nie ma się komu ich opowiadać, a także tęsknienie do mowy polskiej, którą śląskość słyszała i kochała, kiedy była młoda (Kossak, 2014, s. 7-9). 
Niemieckość dla Śląska to czas czekania i mroku; kiedy jednak nastaje chwila, gdy Niemcy muszą wrócić do siebie, to wówczas Polska wraca na Śląsk i jest ona „niesłychana, prawdziwa jak bajka”; kiedy Polska wraca na Śląsk, to dla Śląska nastaje czas pracy i wesela (Kossak, 2014, s. 9-11).

\section{Śląskość jako etniczność, czyli co? Podsumowanie}

Jean-François Lyotard zauważa, że z perspektywy społeczeństwa jego członkowie mogą nie rozpoznać skutków narracji do chwili, w której nie uzyskają dostępu do refleksyjnej wiedzy o swoim społeczeństwie (Lyotard, 1997, s. 47-55). Taka świadomość to kluczowy element momentu emancypacyjnego, gdyż - jak pisałam za Havlem (1993, s. 126-127) - świat homogeniczny, czy też społeczeństwo homogeniczne to społeczeństwo owładnięte „porządkiem śmierci". Społeczeństwo, które dąży do swego wewnętrznego ujednolicenia, $\mathrm{w}$ istocie przeistacza się $\mathrm{w}$ mechanizm, którego jedynym priorytetem jest dążenie do swojej totalności. Zrekonstruowana w tym artykule polska narracja Śląska to przykład narracji, która ma bolesne ontologiczne konsekwencje dla człowieka i całej jego wspólnoty. Przedstawiona rekonstrukcja pozwala rozpoznać zdolność i zarazem skuteczność narracji (w tym przypadku narodowej) w konstruowania politycznej rzeczywistości. Jest ona tym bardziej skuteczna, że jej język jest językiem publicznym. Doskonałym dopełnieniem zrekonstruowanej narracji Kossak są choćby trzy artykuły Ferdynanda Goetla z „Gazety Polskiej. Pismo codzienne” z roku 1934 (Goetel, 1934a, 1934b, 1934c), w których autor przedstawia ówczesne myślenie o Katowicach i Górnoślązakach. Uderza nie tylko naturalistyczna forma tych wypowiedzi, ale przede wszystkim zaskakuje wprost wyłożona formuła tego, czym powinien być Śląsk pod panowaniem polskim i jak usunąć ze Śląska niemieckość. Najbardziej jednak zadziwia sposób pisania o tym, co polskie i o tym, co śląskie, a właściwie katowickie, gdyż Katowice w tej narracji to implicite centrum Śląska. Polskość jest nowym porządkiem, który jaśnieje, i który musi zmienić stary porządek, nadając mu polską formę. Chodzi jednak nie o niemieckość co trzeba raz jeszcze podkreślić - lecz o śląskość, która jest ciemna i brudna od węgła. Odnieść można jednak wrażenie, że nowy porządek - owa jaśniejąca polskość - ma usunąć ze śląskości to ujemne piętno, które odcisnęła na niej niemieckość. Nadrzędną bowiem sprawą jest wytworzenie Polski jako wspólnoty jednolitej i zwartej. Tu ujawnia się logika polskiej śląskości, która obiektywizuje ontologiczną niemożliwość Śląska jako tego, co transparentne. Śląsk może być albo Polską, albo Niemcami. 
Obserwować można w zrekonstruowanej narracji Kossak i przywołanych wypowiedziach Goetla, jak tworzy się totalność „my Polacy - my naród”. Bez tego „my Polacy - my naród” niemożliwa jest polityka narodowa i istniejąca w jej obrębie polityka tożsamościowa. Przywołana wyżej myśl Havla pozwala lepiej zrozumieć nie tylko totalność tak konstruowanej narracji, ale uzmysławia także jej utopijność i - w efekcie - wiarę w możliwość ontologicznego urzeczywistnienia owego „my Polacy - my naród” także w śląskości.

Tożsamość to jednak nie kwestia idei, którą propaguje nawet najlepiej zmontowana metanarracja. Tożsamość to sprawa najbliższej człowiekowi wspólnoty, tego, co zwykle zaczyna się od najbliższego otoczenia i co promieniuje na inne obszary człowieczej egzystencji, decydując o relacji człowieka ze światem swoim i nie swoim. Nie może tożsamość konstruować się inaczej, gdyż to świat stanowi materię, która decyduje o życiowych wyborach człowieka. To, co Havel nazwał ostatecznym horyzontem człowieczej egzystencji, nie może się wobec tego ustanowić bez najbliżej człowiekowi wspólnoty, czyli bez jego „domu egzystencjalnego”; bez fizyczności i duchowości tego „domu”. Tu rozpoczyna się także - wspomniana już wcześniej - odpowiedzialność, lecz nie jest to zwykła odpowiedzialność za coś lub za kogoś. Jest to odpowiedzialność, którą Havel zrównuje z ostatecznym horyzontem ludzkiej egzystencji. I jest to sprawa publiczna, gdyż taka odpowiedzialność dzieje się między ludźmi. I to z tej odpowiedzialności, i z jej publicznego aspektu człowiek zwrotnie konstruuje swoją tożsamość. Dom i najbliższe człowiekowi środowisko nadają sens jego egzystencji. Dlatego też utracić "dom egzystencjalny” w fizyczności to doświadczyć pewnej ontologicznej natarczywości, ale utracić „dom egzystencjalny” w duchowości - to utracić raj ontologiczny. Szczególnie utrata duchowości „domu egzystencjalnego” raz jeszcze powtórzę za Havlem - uzmysławia człowiekowi to, za czym i jak tęskni, o czym i jak myśli oraz wspomina, co i jak sobie wyobraża oraz czego pragnie (Havel, 1993, s. 19-30).

Śląskość w zrekonstruowanej narracji polskości traci swoją transparentność, staje się ona przedmiotem wiedzy, podobnie jak miało to miejsce w narracji niemieckości. Nie bez znaczenia są zatem następujące po sobie ideologie, które zawłaszczają Śląsk.

Każda z ideologii, która dzięki swej narracji zawłaszcza Śląsk, dotyka spraw ontologicznego wymiaru tożsamości śląskiej jako sprawy politycznej. Stąd zapewne ciągły kłopot Ślązaków - podobnie jak i Kaszubów - z tym, że zawsze są oni albo zbyt mało polscy (kiedy jest Polska), albo zbyt mało niemieccy (kiedy były Niemcy). Zawłaszczona odpowiedzialność etniczności 
śląskiej przez wielkie narracje (w tym przypadku narodowe) dąży do takiego przetworzenia śląskości, by Ślązacy byli wyłącznie jako Polacy, albo wyłącznie jako Niemcy. Obie narracje wytwarzają nowe twory, z których jeden to „śląskość jako polskość”, drugi - „śląskość jako niemieckość”. Śląskość przestaje tu być sama przez się zrozumiała, a człowiek-Ślązak w swej ontologii nieustannie doświadczać musi stanu niedoboru, ciągle jest bowiem nie dość: nie dość polski i nie dość niemiecki. O tym ontologicznym dyskomforcie tożsamości pisał przecież Günter Grass w „Blaszanym bębenku”, kiedy odnosił się do Kaszubów: „Tak to już jest z Kaszubami (...) bo my za mało polscy jesteśmy i za mało niemieccy, bo jak ktoś jest Kaszubą, nie wystarcza to ani Niemcom, ani Polakom. Ci zawsze dokładnie chcą wiedzieć, co jest co!" (Grass, 2004, s. 404). Na ten sam problem ontologiczny zwraca uwagę Jolanta Tambor, która w książce „Mowa Górnoślązaków oraz ich świadomość językowa i etniczna" przytacza słowa jednego z uczestników swoich badań: „Bo tak Niemiec powiedzioł na Ślązaka, że jest Polok; a Polok zaś na Ślązaka, że jest Niemiec, tak my mieli. I tak jakby my nie mieli ojczyzny swoji (Jak się żyło: 36)" (Tambor, 2008, s. 58). O tym kłopocie pisał także Horst Bienek w książce „Wrześniowe światło”, kiedy opowiadał o Ślązaku Toniku, który okazał się zbyt mało aryjski, aby przyjęto go do Waffen-SS: „Ja przecież chciałem do Waffen-SS i już jakiś czas temu zgłosiłem się tam na ochotnika, nie mówiłem o tym, to jasne. Jednak tam trzeba mieć chyba niebieskie oczy, włosy blond i dwa metry wzrostu, mniej więcej" (Bienek, 1994, s. 24-25).

Każde społeczeństwa wcześniej czy później nawiedzić musi „duch konstatacji” - jak to metaforycznie ujął Lyotard. Za tą metaforą kryje się niemal wprost wypowiedziana potrzeba wiedzy krytycznej (albo refleksyjnej, bądź hermeneutycznej), która pyta (wprost lub pośrednio) o wartości i cele, i która nie daje się zawłaszczyć (Lyotard, 1997, s. 47-55). Problemem jednak jest to, że jeśli nawet inspiracją momentu emancypacyjnego jest uświadomienie sobie utraty „domu egzystencjalnego” i człowiek zaczyna pytać o ontologiczny sens swej tożsamości, to nie musi to oznaczać, że będzie pytał wprost o swoją etniczność - czyli o śląskość. Bo jeśli śląskość to jest „śląskość jako polskość” albo „śląskość jako niemieckość”, to, jak pokazują powieści Horsta Bienka - i jego osobiste doświadczenia ze „śląskością jako niemieckością” - wraz z przegraną niemiecką pojawia się przegrana śląska. Nie tylko więc Niemcy zostali politycznie zmuszeni do opuszczenia Śląska, ale też i Ślązacy musieli swój Śląsk porzucić.

Emancypacja etniczna to zatem coś, co musi wyzwolić etniczność spod panowania narodowości o innym jądrze etnicznym. W przypadku śląskości szłoby o to, by wyzwolić ją spod „panowania polskiego” (i analogicznie nie- 
mieckiego) - bo tak przecież o polskości w relacji do śląskości pisał Goetel. Etniczna śląskość nie może więc istnieć w wariancie „śląskość jako polskość”; etniczność śląska potrzebuje kooperacji z polskością, co przekładać się musi na imperatyw: „śląskość i polskość”. Tylko tak etniczna śląskość może trwać przy śląskości na przekór historii i polityce granic.

Etniczność wymaga zatem szczególnej troski politycznej nie tyle ze strony państwowości i narodowości o innym rdzeniu etnicznym, te bowiem zawsze będą dążyć do hegemonii poprzez wytwarzanie właściwej sobie narracji o świecie i przekonywać, że ich narracja o świecie jest tym samym co świat. Etniczność wymaga troski od własnej wspólnoty i gotowości jej członków do permanentnego stawiania pytań o swoją etniczność. Człowiek w obrębie swojej wspólnoty z konieczności musi być „bytem pytającym”, jak pisał Havel. Człowiek ma być bytem, „który pyta sam o siebie, a jeszcze ściślej jest on tym, którego ustami byt pyta sam o siebie" (Havel, 1993, s. 76). Człowiek ontologiczny sam dla siebie wybiera swoją społeczną wolność i to, jak ją realizuje (Havel, 1993, s. 26). O tym przecież pisał Horst Bienek, przytaczając wypowiedź Ślązaka: „Pieronie, mój dziadek uprawiał tu już część tego kraju, mój ojciec także, jak miałbym stąd uciec? Właściciel i języki często się tu zmieniały, pieniądze też, raz było nam lepiej, raz gorzej, nie zmienia to ani na jotę tego, że należę do tego kawałka ziemi i moje dzieci również” (Bienek, 1993, s. 327).

\section{Bibliografia}

Bienek, H. 1993. Podróż w krainę dzieciństwa. Spotkanie ze Śląskiem. Gliwice: Wydawnictwo „Wokół nas”: Rafał Budnik \& Marek Kusto.

Bienek, H. 1994. Wrześniowe światło. Gliwice: Wydawnictwo „Wokół nas”: Rafał Budnik \& Marek Kusto.

Bogoczová, I. 2018. Gwara zachodniocieszyńska a język etniczny, czyli wojny językoznawców o Zaolzie. W: Bogoczová, I. Polszczyzna za Olzq. Ostrava: University of Ostrava.

Foucault, M. 2000. Stowa i rzeczy. Archeologia nauk humanistycznych. tom 2. Gdańsk: Słowo/obraz terytoria.

Geertz, C. 2005. Interpretacja kultur. Wybrane eseje. Kraków: UJ.

Goetel, F. 1934a. Katowice. Gazeta Polska. Pismo codzienne. R. VI, nr 227 (17 sierpnia 1934), ss. 5.

Goetel, F. 1934b. Katowice. Powrót kultury. Gazeta Polska. Pismo codzienne. R. VI, nr 235, (25 sierpnia 1934), ss. 5. 
Goetel, F. 1934c. Katowice. Traum oder Schaum. Gazeta Polska. Pismo codzienne. R. VI, nr 238, (28 sierpnia 1934), ss. 5

Grass, G. 2004. Blaszany bębenek. Warszawa: Wydawnictwo Agora S.A.

Havel, V. 1993. Listy do Olgi (czerwiec 1979 - wrzesień 1982). Wybór. Warszawa - Wrocław: Wydawnictwo Naukowe PWN.

Kossak, Z. 1961. Nieznany kraj. Warszawa: Instytut Wydawniczy PAX.

Kossak, Z. 2014. Ktopoty Kacperka, góreckiego skrzata. Lublin: Wydawca Fundacja Servire Veritati Instytut Edukacji Narodowej.

Lyotard, J.-F. 1997. Kondycja ponowoczesna. Raport o stanie wiedzy. Warszawa: Fundacja Aletheia.

\title{
Silesianness as ethnicity: a reflection upon the borderland of Polishness and Silesianness
}

\begin{abstract}
Silesia is a space where the history of Poland, Germany, Czechoslovakia and the Czech Republic have intertwined. It is also a place where great ideologies such as communism and socialism have left their mark. Economic policy also determines Silesia. Therefore, Silesian nature is an example of a culture which was shaped in complicated social and political conditions that determined the cultural awareness of the Silesians themselves as well as their identity. The aim of the article is an attempt to identify how Polishness is constructed within the Polish narrative, and how it promotes (or does not) the emancipation of ethnically Silesian identity. For the purpose of this task, the author analyzed Zofia Kossak's book "Nieznany kraj" (first edition 1931), using the concept of Jean-François Lyotard's metanarration. The second task of the article is a reflection on one of the consequences of Silesian nature becoming entangled in Polishness and Germanity, which means that Silesians are not Polish enough for Poles, and at the same time they are not German enough for Germans? The context of this reflection are the concepts of "culture" as a space for creating meanings (Clifford Geertz) and "world" as human existence (Václav Havel).
\end{abstract}

Keywords: identity, ethnicity, ethnic identity, borderland, Silesia, Polishness 